\title{
STRUCTURAL EQUATION MODELING BASED EMPIRICAL ANALYSIS: DIRECT AND INDIRECT EFFECTS OF JOB SATISFACTION ON JOB PERFORMANCE IN JORDANIAN FIVE-STAR HOTELS
}

\author{
Bandar Ersan Alown ${ }^{1 *}$, Mahadzirah Binti Mohamad ${ }^{2}$, Fazida Karim ${ }^{3}$
}

1 Department of Economic, Universiti Sultan Zainal Abadin (UNISZA), Malaysia Email: bandaraloun@gmail.com

2 Department of Economic, Universiti Sultan Zainal Abadin (UNISZA), Malaysia

Email: mahadzirahmd@unisza.edu.my

3 Department of Economic, Universiti Sultan Zainal Abadin (UNISZA), Malaysia Email: fazidakarim@unisza.edu.my

* Corresponding Author

\section{Article Info:}

\section{Article history:}

Received date:23.01.2020

Revised date: 04.02.2020

Accepted date: 13.03.2020

Published date: 15.03 .2020

\section{To cite this document:}

Alown, B. E., Mohamad, M., \& Karim, F. (2020). Structural Equation Modeling based Empirical Analysis: Direct and Indirect Effects of Job Satisfaction on Job Performance in Jordanian Five-Star Hotels. Journal of Tourism, Hospitality and Environment Management, 5 (18), 133-151.

DOI: 10.35631/JTHEM.5180012.

\section{Abstract:}

In order to improve and maintain competitiveness in the hotel sector, the key elements of success must be available, which is headed by an efficient employee, so it is essential that the employees' performance be at its best. This study examined the effect of job satisfaction (JS) on job performance (JP), organisational structure (OS) and leadership style (LS) on (JS), and Quality of work-life (QWL) on (JP) among five-star hotels employees in Jordan. The study also examined the moderating role of quality of work-life on the variable's relationships. A questionnaire was used as the main instrument for data collection from 430 employees of five-star hotels. Data analysis was conducted with the help of Structural Equation Modelling (SEM) to determine the level of relationships among (JS), (OS), (LS), (JP), and (QWL). According to the obtained findings, there is a positive relationship between JS and QL on JP, and QWL has a partial moderating role in the relationship between JS and JP. The study findings motivate future studies to carry out studies of the same caliber in other sectors of Jordan, and also in other contexts based on different perspectives.

\section{Keywords:}

Job Performance, Quality Of Work Life, Hotel, Jordan 


\section{Introduction}

Ever since the $20^{\text {th }}$ century, tourism has emerged as a growing and important sector of the Jordanian economy. According to the UNWTO Report (2017), the tourism industry globally offered employment to 10 million people in 2017. More than a billion people travelled the world as tourists and spent USD 1.4 (around $£ 837 \mathrm{Bil}$ ). The tourism sector continues to grow and its upcoming is predicted to be bright according to the same report. This continuing expansion of tourism globally is due to a few important factors: the emergence and popularity of low-cost airlines offering affordable air travel other transportation developments increasing growing levels of disposable income and development, relatively unexplored destinations like China and India (Zu et al., 2015).

In the context of Jordan, its tourism sector is a very important sector. For this kingdom, tourism generates huge foreign exchange resources for the treasury. For instance, the total input of Travel and Tourism to GDP was USD7, 640.7 million, 19.4\% of GDP in 2016 (WTTC, 2017). In 2017, Jordan hosted 5.4 million visitors from all over the globe. Meanwhile, according to Al-Rousan and Mohamed, (2010), Jordan's tourism sector is led by companies operating in the hotel sector. Moreover, Jordan's Vision 2020 targets the creation of a tourism industry that is complete, world-standard and which can contribute significantly to the country's economy to help drive development, enable equality in income opportunity distribution nationwide, influence the government investment policy and promoting Jordan as a destination of choice that is safe, secure, and offering a sustainably managed environment (USAID, 2006). The present study on the hotel industry will be conducted in the content of Jordanian tourism and aligned with its current status and its planned future development.

Besides the many attractions of Jordan, the four key destinations of Jordanian tourism are: Amman, Petra, Dead Sea, and Aqaba. Amman is the Jordanian capital as well as the administrative, industrial and commercial heart of the country. Global Hospitality Services Rosenberg \& Choufany, (2009), has reported on the exceptionally rapid development of medical tourism in Amman over recent years. The second key destination is Petra, which has been recently accorded the distinction of being one of the 'World New Seven Wonders'. Like a precious jewel hidden from the outside words, Petra offers the visitor many temples and tombs carved into a look of coloured sandstone rocks. Not surprisingly, Petra is the country's most visited tourist attraction, which offers a rich mix of history, culture and religion (MOTA, 2014). The third important destination is the Dead Sea, as it's unique in some ways: it is the lowest spot on earth, and its body of water is the saltiest and has the highest concentration of minerals in the world. Additionally, the Dead Sea has also developed into a unique rehabilitation, health and beauty treatment centre. The coastal city of Aqaba is the fourth key destination of Jordanian tourism. It is located $300 \mathrm{~km}$ south of Amman and at the junctions of three countries (i.e., Egypt, Saudi Arabia and Israel). Aqaba is known as it's the best for its warm water and the wealth of marine life and therefore a haven for divers. It is the destination for sun, sand and sea lovers in the region.

Furthermore, upscale hotels in Amman and Aqaba general are exposed to several problems related to human resources (e.g. the lack of qualified workforce, the high rate of employment turnover, and employee stress). These hotels are also exposed to some challenges related to their core operation processes (e.g. high competition, seasonality, and high customers' expectations). These challenges and problems may decrease upscale hotels overall performance in general and their job performance in particular. According to Hahn et al., 
(2005), the hotel industry is facing increased competition, globalisation, greater customer turnover, rising customer expectations and growing customer acquisition costs, which mean that competitiveness and performance in hotels are significantly dependent on their ability to satisfy customers effectively and efficiently. Therefore, these challenges and problems in Amman and Aqaba need more attention from professionals as well as researchers in order to recommend some innovative solutions. Thus, upscale Jordanian hotels in Amman and Aqaba represent an ideal context for an investigation into the impact of the consequence of job satisfaction on job performance.

\section{Job Performance (JP)}

Job performance play important role in sustaining the business especially in hospitality organisations. This is because hospitality organisation requires employees to coordinate multiple services in order to provide a task environment that has to be well organized. Moreover, Hospitality organisations are a complex and heterogeneous organisation because it requires coordinating multiple services in order to provide a task environment that has to be well organized. Besides this, employees have to ready to solve different type of ad hoc problem in a continuously changing environment. For hotel to survive commercially, they have to implement a good strategic plan to deal with the rapid change of technology and competitive industry. There is study stated that less than thirty percentage of organisations in the service industry successfully implement strategic planning (Nabwire, 2014). This failure was caused by organisational factors such as leadership styles and organisational structure (Sekaran \& Bougie, 2010). Thus, it is important to present study further investigate whether organisation structure and leadership style are influencing employee performance that leads to failure of strategy implement.

Also, job performance entails the individual's assessment if the job has been performed soundly. Job performance is a dependent variable that has been explored for a long time. Accordingly, Borman \& Motowidlo, (1993) mentioned two employee behaviour types that highly impact the effectiveness of organisation namely: task performance and contextual performance. Task performance comprises behaviours closely related to the production of activities, service or good that provide certain procedures to the organisation (Borman \& Motowidlo, 1993; Werner, 2000), and they are closely related to the organisation's mechanism of formal reward. On the other hand, contextual performance refers to the individual's effort indirectly associated with their main task functions. These behaviours shape the psychological, organisational and social contexts which are the essential catalysts for processes of task and activities (Werner, 2000).

Job performance has relation to the conduct of a job. Thus, Campbell et al., (1993) perceive job performance as a multidimensional conception for goal attainment. Task performance refers to the behaviours perceived by the frameworks of formal reward and is a requirement in job descriptions (Williams \& Anderson, 1991). What a person goes through by the end of the week May increase assets that can be unmistakable in expanded undertaking execution following the weekend. Proactive behaviours comprise actions that are future arranged completely, and as mentioned Crant, (2000) this type of behaviour is associated with taking the initiative in generating better circumstances for the current time or establishing new circumstances. This type of behaviour challenges the status quo; it does not simply adapt to the present circumstances obediently. As stated by George, (1991) proactive performance is 
especially vital for organisations. This is because it is not possible to predict all the behaviours necessary in attaining the organisational goals.

\section{Organisational Structure (OS)}

An organisation includes an entity that contains countless individuals and is established by groups of individuals as an attempt to attain impacts that cannot be achieved with one individual. As reported by Maduenyi et al, (2015) better outcomes are attainable from hierarchical effect directing organisation to attain certain organisational goals.

Profitable organisations, as well as non-profitable organisations, exist. In order to achieve their objectives, organisations form inner relations and order among their organisational parts (or organisational structure). As a guarantee of legitimate functioning, all parts of an organisation such as specialization, decisions involvement, formal standardization, and punishment, together with relations as well as their coordination components are integral. Countless components impact organisations and these components come from the dynamic environment or from the organisation itself. Organisational structure is static in nature which may cause failure in satisfying the proficiency and adaptability requirements. Classic organisation theories epitomized various disciplines of factors that impact on organisational structure, and according to (Tran \& Tian, 2013), some are of the view that factors such as environment and technology or size, influence organisational structure.

Structure entails one session arrangement and arrangement of interrelated elements within a system or material object and the organisation of duties employed for the work to be done, and this, according to Jackson \& Cyril, (1982) is best symbolized by the organisation chart. The structures include the generation of talent, leadership, functional relationships, business capability and arrangement (Katunze et al., 2017). The structure comprises the sorting out grounds, including the responsibility boundaries as well as hierarchical levels, positions and roles, and system for problem-solving and for integration (Walton, 1986). The structure also models the relationships and the inner disparity and is the means used by the organisation in establishing restrictions and boundaries to guarantee efficient performance exhibited by its members, that is, by controlling the resources, allocating accountabilities as well as other matters (Thompson, 1967).

With all above considered, organisational structure is, therefore, the commonly hierarchical arrangement of the organisation's lines of communications, duties authority and rights. Mintzberg, (1979) refers to organisational structure as a set of methods breaking organisation down into separate tasks and then harmony is created between differing duties. Organisational structure also includes the formal mechanism of the task and reporting relations, coordinating, controlling and motivating employees in gaining their cooperation so that the goals of the organisation could be reached (Hassan et al., 2013.

\section{Leadership Style (LS)}

Leadership is a social influence process. Here, as explained by Nanjundeswaraswamy \& Swamy, (2014) the leader seeks for the measured investment of subordinates to reach the organisation's objectives and gain awareness of what to be achieved and how. A leader is someone who allocates or influences others to engage in certain actions to achieve the objectives specified. At the present time, effective leaders with the awareness of the complexities of the expeditiously ever-changing global environment are of value. Leaders have a close relationship with the subordinates, and with respect to representatives, sufficiency will 
be great. A task that is very structured alongside a leader maintains good relationship with the employees will lead to the creation of employees that are very effective. Leadership is currently an important concept in the context of management.

Leadership is a concept based on "Great Man" theory. Supporters of Great Man theory are of the view that leaders are born, and they have intrinsic qualities, that is, the leader is not made. Further, this theory purposely refers to males with the usage of the word 'Man.' With respect to this matter, Bolden, (2004) provides an explanation: leaders have been generally viewed as successful individuals in their military undertakings, and nearly all these individuals were mostly men. Similar to great man theory, researchers have tried to describe the significant attributes that make leaders different from their followers. The notion of good leaders or potential ones has been referred by McCall \& Lombardo, (1983) and Stogdill (1974) as those motivated, responsive, energetic, assertive, achievement-orientated, determined, decisive, adaptive, as well as self-confident people. Leader behaviour can inspire and fulfil the representatives, and it is also a strong platform as support for the employee's work engagement.

The use of different leadership styles can lead to better work engagement of employees (Bakker et al., 2011).

Leadership theory at the present time entails the characterization of behavioural styles that a leader exhibits, beyond being mere attributes. Accordingly, the behavioural model comprises the components of a leader's behaviour, suggesting that leaders can be created, proving linkage to the situational theory of leadership which mentions that a suitable behaviour of leader will be dictated by the situation (Robbins, 2009). On the other hand, the Trait Theory posits that certain physical qualities and identity attributes are possessed by the perceived leader, and these distinguish them from those viewed as non-leaders. The hypotheses of characters are not concerned with the question of whether resource fullness qualities were nature or nurtured. In this context, Jenkins identified two traits namely self-confidence and effectiveness and emergent traits. Self-confidence and effectiveness are shaped by the person's learning or experience, while emergent traits mostly grounded on heredity which includes the physical characteristics, intelligence, as well as attractiveness including charisma that the person possesses. All these are the rudimentary components of leadership (Ekvall \& Arvonen, 1991).

\section{Job Satisfaction (JS)}

Job satisfaction entails a constructive state of emotion emerging from a job experience that is positive. The notion of job satisfaction has been a widely explored form of job attitude. It is in fact, among the subjects that have been most painstakingly researched in organisations (Locke, 1976). In this context, employees shape their attitude towards their jobs with their feelings, beliefs, and behaviours being under consideration (Akehurst et al., 2009). Job satisfaction refers to a representative's subjective standpoint towards the business circumstances in terms of the linkage between the employee and the employer, while emotion is impacted by values and beliefs inherent to the employees (Quinlan et al., 2019).

Also, job satisfaction refers to the employee's feeling of accomplishment at the workplace. Job satisfaction is generally related to a person's efficiency and success; it can be experienced following the performance of a task that one finds enjoyable, can do well and gets rewarded for performing it. Job satisfaction is also a demonstration of a person's sense of happiness and enthusiasm with his/her work. Job satisfaction is the key component contributing to income, 
promotion, appreciation and the fulfilment of other goals, leading to the feeling of gratification (Kaliski, 2009).

Mohamad et al., (2018) have stressed the great importance of job satisfaction inside an organisation, which brings to a list of factors associated with employees' satisfaction with their job by Schein, (2006) namely: autonomy, job security, managerial capability, demanding tasks, feeling of committed service, technical ability, innovation, creativity, and lifestyle.

There appears a strong connexion between employee's job satisfaction and Job performance (Kinnie et al., 2005). Also, several factors have been linked to job satisfaction Mohamad et al., (2014) namely: working condition, benefits, salary, job assignment, recognition, co-workers, supervisor, promotions, and management. Moreover, the theories applied and established in organisations in the West and in other Non-western organisations are equally validated (Yousef, 2000). Thus, it can be assumed that the exceptional effect of leadership style on job satisfaction is comparable for organisations in both west and east regions. In relation to this, Lok \& Crawford, (2004) mentioned the dominance of this aspect in organisation's success or failure.

\section{Quality of Work Life ( $Q W L)$}

A person is capable of having a private, public and also secret life. The life of a person is a reflection of his/her decisions formed within the confines of constraints and information. Genes and income affect the opportunities individuals' have. Families, place of birth and community characterize the belief of a person towards what constitutes a quality work life. What a person feels towards the nature of his/her life is dictated by the person's memories and histories. People should carefully comprehend the notion of life work quality since good life is not merely good consumption, distribution and production. The book elaborates the subtle relationship between achievement and importance that countless keen individuals experience. People should know what everything signifies, and that their personal wealth is impacted by something including contentment, virtue, and fulfilment. It means that people seek something that makes life meaningful. The good life quest is interpretable as the good life (Massam, 2002).

Planners mostly concentrate on making the quality of work life (QWL) better in some place or for some group or individual. We could go encourage and propose that the venture of arranging as an open action is unequivocally inspired and legitimized as far as the commitments it conceivably can make to the quality of work life of citizens. "Planning in the Public Domain, "written by Kumar and Rajendran, (2018) refers planners as those holding a huge responsibility in impacting the open, responsible and legitimate societies wherein evaluations are made on the complex choices whereas plans are executed. Such plans directly affect the private and public good and the quality of work life of the citizens as well.

Attempts have been demonstrated by non-governmental organisations, politicians, bureaucrats, alongside the public to influence the processes and outcomes of planning. The purpose was to change the circumstances that are seen as detrimental to life work quality (Massam, 2002). At the same time, projects perceived as improving and preserving the cultural and material background which make life work quality better, are promoted.

The four-qualities-of-work life framework concerns the assessment rather than the description of the quality of lives of individuals. The quality and indulgence of individuals and of their 
lives that seem multiple-sided are recognized by this framework. Thus, high-level open arrangement plan and assessment are required by the framework. Further, public policy should cover other issues beyond income, such as the key aspects of the individual's life work quality. In this context, Rojas, (2014) suggests the inclusion of issues of life satisfaction, individual's affective states, volunteerism, production of relational goods and so forth.

Aligned with the present study's objectives and the reviewed literature, the following hypotheses are proposed to be tested;

H1A: Organisation structure has a significant influence employees' job satisfaction in the Jordanian hotels sector.

H1B: Leadership style has a significant influence on employees' job satisfaction in the Jordanian hotels sector.

H2: employees' job satisfaction has a significant influence on their job performance in the Jordanian hotels sector.

H3: Employees' job satisfaction has a significant influence on their quality of work life.

H4: Employees' quality of work life has a significant influence on their job performance.

H5: Quality of work life mediates the relationship between job satisfaction and job performance.

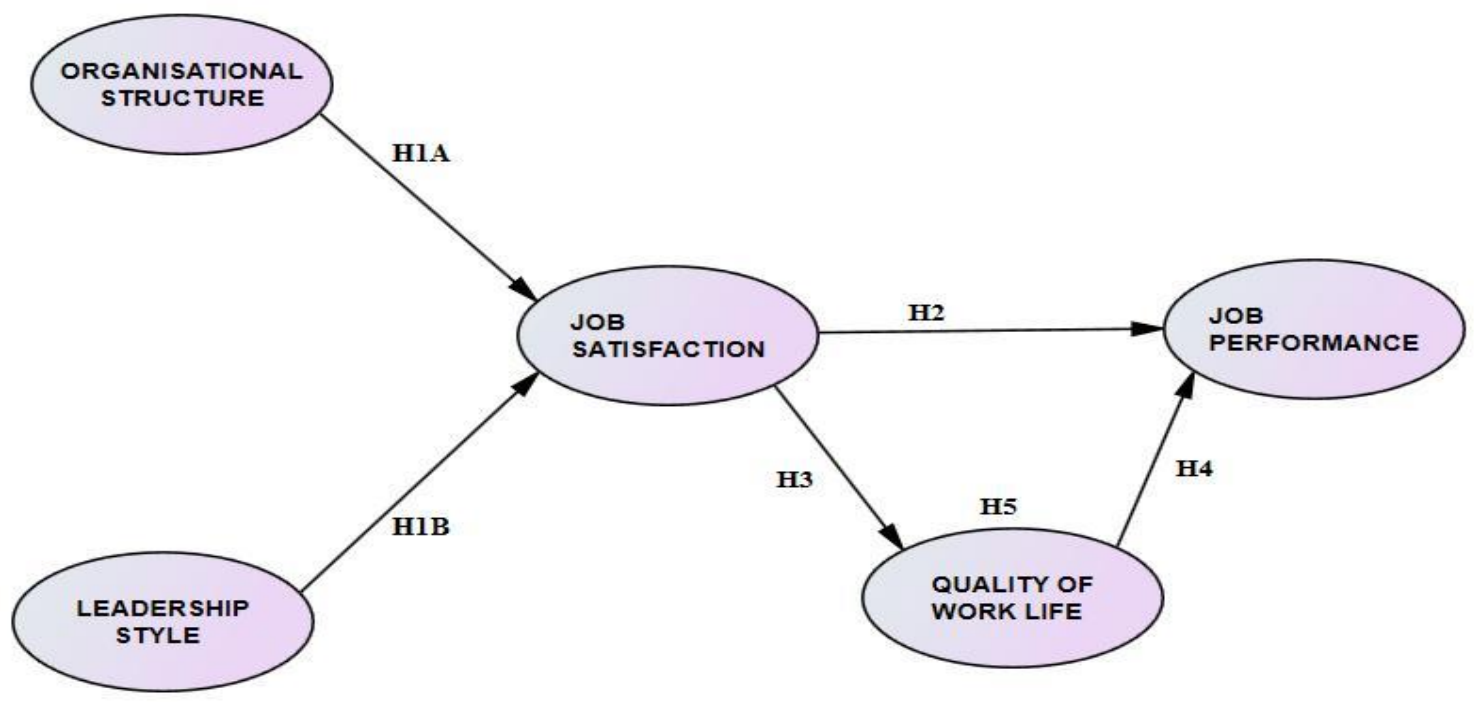

Figure 1: The Conceptual Framework

\section{Research Methodology}

This study primarily aims to examine the effects of job satisfaction, organisational structure, leadership style, and quality of work life on job performance. The study also examines the moderating role of quality of work life on the relationships. Primary data was collected using the primary instrument, questionnaire survey, based on Hayes, (2017) indicated that There are a number of benefits associated with this method of data gathering. Firstly, this instrument of 
data gathering enables the researcher to exhaustively summarize the attitudes, thoughts as well as the behavior of the sample. At the same time, considering that these self-administered questionnaires being distributable to a significant number of respondents, and can also be sent via email, this method is efficient in terms of cost and time. Thirdly, the distribution of questionnaires is simple to do and therefore, it is less prone to errors. Lastly, questionnaires support anonymity and thus, the respondents would feel sufficiently comfortable in expressing their opinions as well as experiences.

Response rate defined by Sekaran \& Bougie, (2016) as the percentage of respondents who participated in the survey from the sample size determined for the research. The response rate is important to ensure the questionnaires collected are valid for data analysis (Hair et al., 2017). An 20\% increase was made on the 384 required sample size to avoid missing and incomplete questionnaires. Hence, a total of 649 questionnaires were distributed among frontline employee in the Jordanian hotel's industry, were 200 used for the pilot study and 449 made for actual data. In total, from 449 questionnaires, 430 were returned equivalent to $96 \%$ response rate. In particular, a minimum adequate response rate in survey studies is $30 \%$ (Sekaran \& Bougie, 2016). Therefore, the study response rate is highly adequate for further analysis. Table 1 presented the detailed information on the number of a questionnaire distributed, returned, and response rate.

Table 1: Summary of Response Rate

\begin{tabular}{|c|c|c|c|c|}
\hline No & Hotel & $\begin{array}{l}\text { Questionnaire } \\
\text { Distributed }\end{array}$ & $\begin{array}{l}\text { Questionnaire } \\
\text { Returned }\end{array}$ & $\begin{array}{l}\text { Response } \\
\text { Rate }(\%)\end{array}$ \\
\hline 1. & Fairmount & 18 & 18 & $100 \%$ \\
\hline 2. & Intercontinental Amman & 23 & 23 & $100 \%$ \\
\hline 3. & Grand Millennium & 21 & 21 & $100 \%$ \\
\hline 4. & Kempinski & 16 & 16 & $100 \%$ \\
\hline 5. & Le Grand & 21 & 20 & $95 \%$ \\
\hline 6. & Amman Marriot & 17 & 17 & $100 \%$ \\
\hline 7. & Grown Plaza & 16 & 16 & $100 \%$ \\
\hline 8. & Grand Hayatt & 13 & 12 & $92 \%$ \\
\hline 9. & The Boulevard & 20 & 20 & $100 \%$ \\
\hline 10. & Sheraton & 29 & 28 & $97 \%$ \\
\hline 11. & Four Season & 10 & 10 & $100 \%$ \\
\hline 12. & Landmark & 50 & 48 & $96 \%$ \\
\hline 13. & Amman Rotana & 25 & 22 & $88 \%$ \\
\hline 14. & W. Amman & 24 & 24 & $100 \%$ \\
\hline 15. & Bristol & 26 & 24 & $92 \%$ \\
\hline 16. & Movenpick & 31 & 29 & $94 \%$ \\
\hline 17. & Double Tree & 25 & 24 & $96 \%$ \\
\hline 18. & Intercontinental & 19 & 19 & $100 \%$ \\
\hline 19. & Oryx & 13 & 11 & $85 \%$ \\
\hline 20. & Tala Bay & 15 & 13 & $87 \%$ \\
\hline \multirow[t]{2}{*}{21.} & Isrotel Agamin & 17 & 15 & $88 \%$ \\
\hline & Total & 449 & 430 & $96 \%$ \\
\hline
\end{tabular}




\section{Measurement of Constructs}

The constructs measurements were adopted from prior studies; more specifically, job performance instrument was adapted from the work of (Valaei \& Jiroudi, 2016), the instruments contain 4 items in using a 5-point Likert scale ranging from 1 as highly disagree to 5 as highly agree, quality of work life instrument was adapted from the work of (Sajtos et al., 2015), the instruments contain 8 items in using a 7-point Likert scale ranging from 1 as highly disagree to 5 as highly agree, job satisfaction instrument was adapted from the work of (Hassi, 2018), the instruments contain 5 items in using a 5-point Likert scale ranging from 1 as highly disagree to 5 as highly agree, leadership style instrument was adapted from the work of (Sanda \& Arthur, 2017), the instruments contain 5 items in using a 5-point Likert scale ranging from 1 as highly disagree to 5 as highly agree, and organisational structure instrument was adapted from the work of (valaei, 2017), the instruments contain 5 items in using a 7-point Likert scale ranging from 1 as highly disagree to 5 as highly agree.

\section{Confirmatory Factor Analysis (CFA)}

This study intends to validate the main construct namely job performance, quality of work life, job satisfaction, leadership style and organisational structure using pooled CFA procedure. The study decided to employ the Pooled-CFA since it is more efficient, thorough, and free from model identification problem (Awang et al., 2015; Awang, 2014). Using this method, all constructs are pooled together and linked using the double-headed arrows to assess the correlation among the constructs as shown in Figure 2.

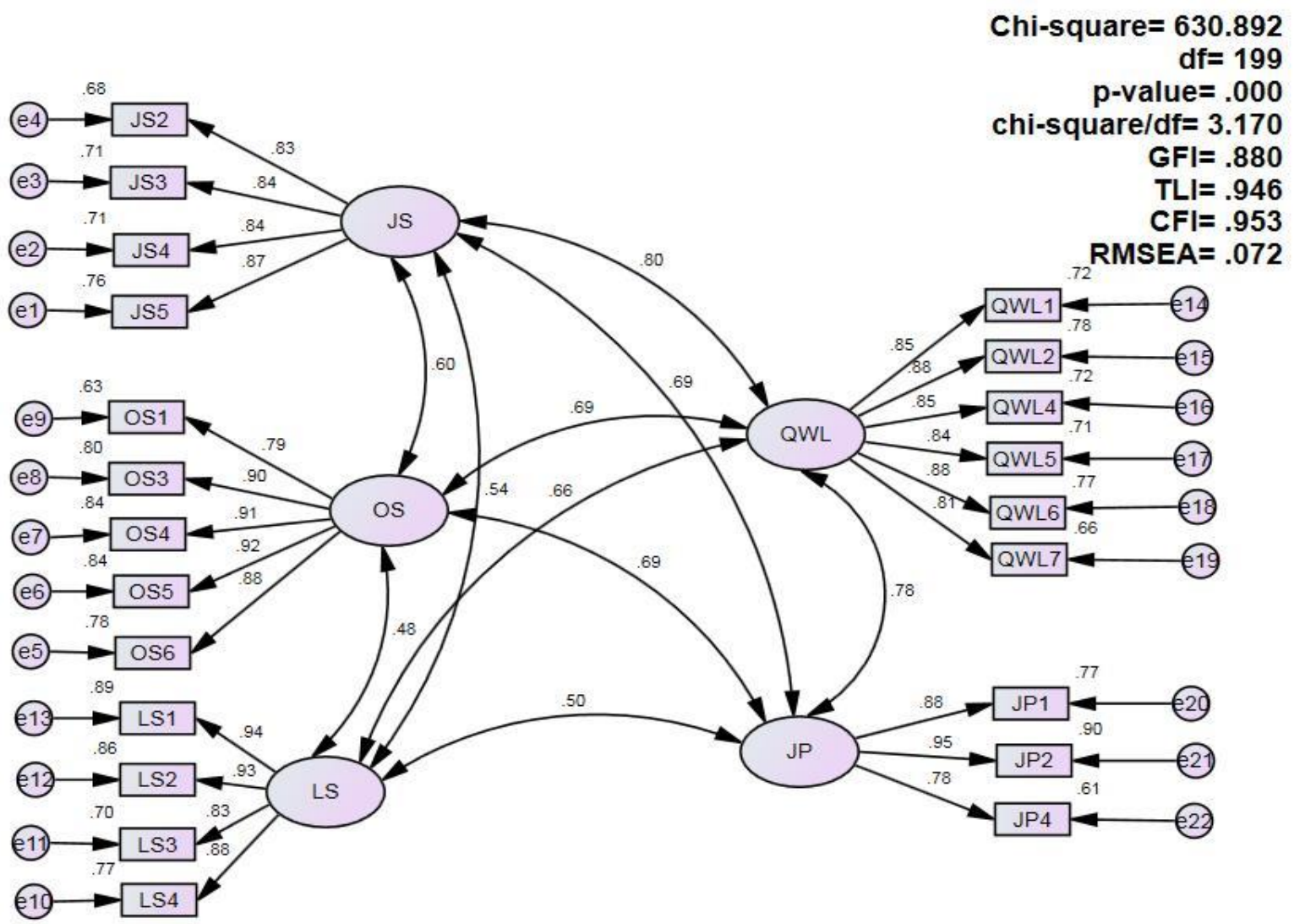

Figure 2: The Pooled-Confirmatory Factor Analysis for All Constructs 


\section{Assessment of Validity and Reliability of the Constructs}

\section{Construct Validity}

The fitness indices achieved the fitness indices indicators established recommended values. In particular, Absolute Fit (RMSEA) is 0.072, Incremental Fit (CFI) is 0.953, and Parsimonious Fit (Chisq/Df) is 3.170, confirming the presence of construct validity as recommended by Aziz et al. (2016), Afthanorhan et al. (2017; 2018; 2019).

\section{Convergent Validity}

This type of validity can be assessed through the calculation of the Average Variance Extracted (AVE), using each item's factor loadings on their respective constructs. In this respect, the AVE for the individual constructs is as follows; 0.761 for job performance, 0.713 for job satisfaction, 0.805 for leadership, 0.652 for organisational structures, and 0.730 for quality of work life The AVE values are all higher than 0.50 and thus, all five constructs' convergent validity were confirmed.

\section{Composite Reliability (CR)}

This type of construct reliability can be assessed using each item's factor loading on their corresponding construct and for CR of the study constructs, they are; 0.905 for job performance, 0.908 for job satisfaction, 0.943 for leadership style, 0.918 for organisational structure, and 0.940 for quality of work life, which all exceed 0.60 , and thus, composite reliability of the constructs is confirmed.

\section{Discriminant Validity}

The Discriminant Validity was achieved when a square root of AVE is higher than the correlations values among constructs. The study needs to assess the Discriminant Validity of the constructs to clarify that they are not redundant with each other. The study also needs to develop the Discriminant Validity Index Summary for all constructs involved in the model to ensure that they are discriminant among each other. The Discriminant Validity Index Summary is shown in Table 2.

Table 2: Discriminant Validity -Fornell Lacker

\begin{tabular}{lccccc}
\hline Construct & $\begin{array}{c}\text { Job } \\
\text { Performance }\end{array}$ & $\begin{array}{c}\text { Job } \\
\text { Satisfaction }\end{array}$ & $\begin{array}{c}\text { Leadership } \\
\text { Style }\end{array}$ & $\begin{array}{c}\text { Organisation } \\
\text { Structure }\end{array}$ & $\begin{array}{c}\text { Quality } \\
\text { of work } \\
\text { life }\end{array}$ \\
\hline Job Performance & $\mathbf{0 . 8 7}$ & & & & \\
Job Satisfaction & 0.67 & $\mathbf{0 . 8 4}$ & & & \\
Leadership Style & 0.50 & 0.54 & $\mathbf{0 . 9 0}$ & & \\
Organisation Structure & 0.69 & 0.60 & 0.48 & $\mathbf{0 . 8 1}$ & \\
Quality of work life & 0.78 & 0.80 & 0.66 & 0.69 & $\mathbf{0 . 8 5}$ \\
\hline
\end{tabular}

\section{Assessment for Construct Validity and Reliability}

The Maximum Likelihood Estimator (MLE) was used to test the normality distribution in SEM and this is possible through the values of Skewness and Kurtosis of every item. The results of normality assessment of the constructs are presented in Table 3. 
Table 3: The Assessment of Normality for all Items in the Study

\begin{tabular}{lllllll} 
Item & & & & Kurtosis & \\
& Valid & Missing & Statistics & SE & Statistic & SE \\
\hline JP1 & 430 & 0 & 0.687 & 0.118 & -0.473 & 0.235 \\
JP2 & 430 & 0 & 0.792 & 0.118 & -0.525 & 0.235 \\
JP3 & 430 & 0 & 0.755 & 0.118 & -0.716 & 0.235 \\
JP4 & 430 & 0 & 0.872 & 0.118 & -0.077 & 0.235 \\
QWL1 & 430 & 0 & 0.491 & 0.118 & -0.657 & 0.235 \\
QWL2 & 430 & 0 & 0.498 & 0.118 & -0.881 & 0.235 \\
QWL3 & 430 & 0 & 0.285 & 0.118 & -0.388 & 0.235 \\
QWL4 & 430 & 0 & 0.323 & 0.118 & -0.846 & 0.235 \\
QWL5 & 430 & 0 & 0.678 & 0.118 & -0.875 & 0.235 \\
QWL6 & 430 & 0 & 0.193 & 0.118 & -1.014 & 0.235 \\
QWL7 & 430 & 0 & 0.509 & 0.118 & -1.045 & 0.235 \\
QWL8 & 430 & 0 & 0.540 & 0.118 & -0.603 & 0.235 \\
JS1 & 430 & 0 & 0.077 & 0.118 & -1.027 & 0.235 \\
JS2 & 430 & 0 & 0.339 & 0.118 & -1.138 & 0.235 \\
JS3 & 430 & 0 & 0.208 & 0.118 & -0.967 & 0.235 \\
JS4 & 430 & 0 & 0.177 & 0.118 & -1.314 & 0.235 \\
JS5 & 430 & 0 & 0.189 & 0.118 & -1.177 & 0.235 \\
LS1 & 430 & 0 & 0.651 & 0.118 & -0.874 & 0.235 \\
LS2 & 430 & 0 & -0.045 & 0.118 & -1.038 & 0.235 \\
LS3 & 430 & 0 & 0.134 & 0.118 & -0.764 & 0.235 \\
LS4 & 430 & 0 & -0.003 & 0.118 & -0.763 & 0.235 \\
LS5 & 430 & 0 & 0.112 & 0.118 & -0.900 & 0.235 \\
OS1 & 430 & 0 & 0.302 & 0.118 & -1.133 & 0.235 \\
OS3 & 430 & 0 & -0.019 & 0.118 & -0.828 & 0.235 \\
OS4 & 430 & 0 & -0.559 & 0.118 & -0.400 & 0.235 \\
OS5 & 430 & 0 & 0.498 & 0.118 & -1.072 & 0.235 \\
OS6 & 430 & 0 & 0.750 & 0.118 & -0.642 & 0.235 \\
\hline & & & & & & \\
\hline
\end{tabular}

many scholars claimed that the acceptable limits between -2 and +2 are considered acceptable to prove normal univariate distribution (Gravetter \& Wallnau, 2016; Ao \& Gelman, 2011; George \& Mallery, 2010). Based on this recommendation the absolute values of the skewness in this study is within the range of -0.559 to 0.872 , while kurtosis is within the range of 1.314 to -0.077 which are within the acceptable range of -2 and +2 as shown in Table 3 .

The next step involves the drawing of the structural model and the execution of the Structural Equation Modelling (SEM) for the estimation of the required parameters. Figure 3 presents the SEM output of standardized regression path coefficients between constructs, while table 4 presents the normal regression path coefficients between them. 


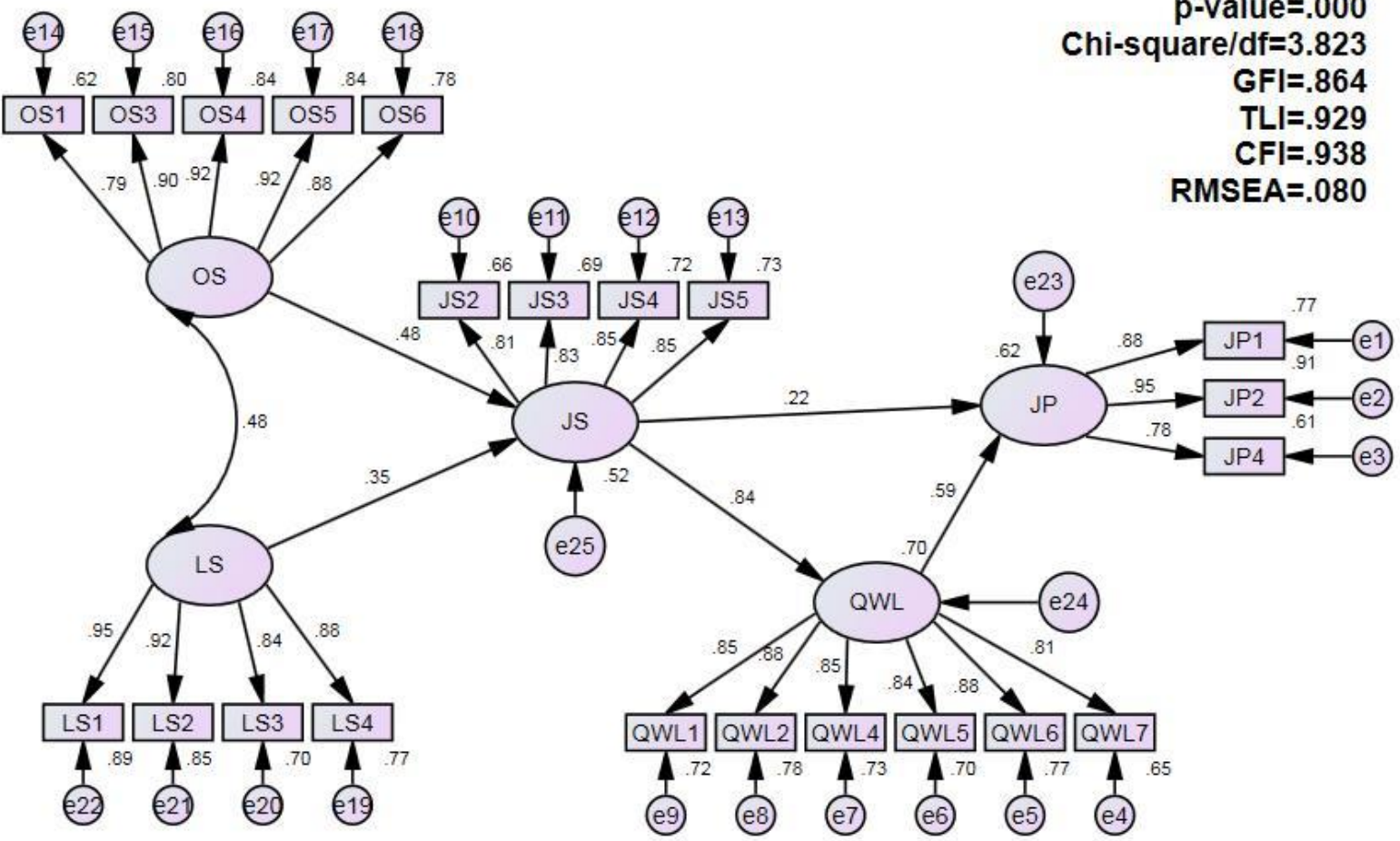

Figure 3: The Standardized Regression Path Coefficient between Constructs

Table 4: The Regression Path Coefficient and Its Significance Based on $p$-value $<0.05$

\begin{tabular}{|c|c|c|c|c|c|c|c|c|}
\hline \multicolumn{3}{|c|}{$\begin{array}{l}\text { Structural } \\
\text { Relationship }\end{array}$} & \multirow{2}{*}{$\begin{array}{c}\text { Standardised } \\
\text { Estimate/Beta } \\
0.48\end{array}$} & \multirow{2}{*}{$\begin{array}{c}\begin{array}{c}\text { Estimate } \\
\text { (Actual } \\
\text { Beta) }\end{array} \\
0.52\end{array}$} & \multirow{2}{*}{$\begin{array}{c}\text { S.E. } \\
0.054\end{array}$} & \multirow{2}{*}{$\begin{array}{l}\text { C.R. } \\
9.704\end{array}$} & \multirow{2}{*}{$\begin{array}{c}\begin{array}{c}\mathrm{P}- \\
\text { value }\end{array} \\
* * *\end{array}$} & \multirow{2}{*}{$\begin{array}{l}\text { Result } \\
\text { Significant }\end{array}$} \\
\hline JS & $\begin{array}{l}<- \\
-\end{array}$ & OS & & & & & & \\
\hline JS & $\begin{array}{l}<-- \\
-\end{array}$ & $\mathrm{LS}$ & 0.35 & 0.25 & 0.032 & 7.786 & $* * *$ & Significant \\
\hline QWL & $\begin{array}{l}<-- \\
-\end{array}$ & JS & 0.83 & 0.84 & 0.048 & 17.708 & $* * *$ & Significant \\
\hline JP & $\begin{array}{l}<-- \\
-\end{array}$ & JS & 0.22 & 0.23 & 0.079 & 2.994 & .003 & Significant \\
\hline JP & $\begin{array}{l}<-- \\
-\end{array}$ & QWL & 0.59 & 0.62 & 0.081 & 7.697 & $* * *$ & Significant \\
\hline
\end{tabular}

\section{Testing the Hypotheses}

H1A: Organisation Structure Has A Significant Influence Employees' Job Satisfaction In The Jordanian Hotels Sector

As predicted, organisational structure was found to have positive effects on job satisfaction $(\beta=0.528, \mathrm{p}=0.001)$. In other words, when organisational structure went up by 1 , job Copyright $\odot$ GLOBAL ACADEMIC EXCELLENCE (M) SDN BHD - All rights reserved 
performance also went up by 0.528 . Thus, the above research hypothesis is supported as presented in Table 5.

Table 5: The Significant Effect Of Organisational Structure And Job Satisfaction

\begin{tabular}{cccccccc}
\hline Construct & Path & Construct & $\begin{array}{c}\text { Beta } \\
\text { Estimate }\end{array}$ & $\begin{array}{c}\text { Standard } \\
\text { Error }\end{array}$ & $\begin{array}{c}\text { Critical } \\
\text { Region }\end{array}$ & $\begin{array}{c}\text { P- } \\
\text { Value }\end{array}$ & Result \\
\hline JS & $<---$ & OS & .528 & .054 & 9.704 & $* * *$ & Supported \\
\hline
\end{tabular}

H1B: Leadership Style Has A Significant Influence On Employees' Job Satisfaction In The Jordanian Hotels Sector

This finding of this study shows that leadership style was found to have a significant and positive relationship with job satisfaction $(\beta=0.251, p=0.000)$. In other words, the output shows that when leadership style went up by 1 , job satisfaction also went up by 0.251 . Thus, it can be concluded that leadership style has a positive effect on job satisfaction and hypothesis $\mathrm{H} 1 \mathrm{~b}$ is supported as presented in Table 6 .

Table 6: The Significant Effect of Social Support and Mental Health

\begin{tabular}{cccccccc}
\hline Construct & Path & Construct & $\begin{array}{c}\text { Beta } \\
\text { Estimate }\end{array}$ & $\begin{array}{c}\text { Standard } \\
\text { Error }\end{array}$ & $\begin{array}{c}\text { Critical } \\
\text { Region }\end{array}$ & $\begin{array}{c}\text { P- } \\
\text { Value }\end{array}$ & Result \\
\hline JS & $<---$ & LS & .251 & .032 & 7.786 & $* * *$ & Supported \\
\hline
\end{tabular}

\section{H2: Employees' Job Satisfaction Has A Significant Influence On Their Job Performance} In The Jordanian Hotels Sector

As hypothesised, job satisfaction was found to be positively related to job performance $(\beta=0.238, p=0.003)$. According to the results, when job satisfaction went up by 1 , job performance also went up by 0.238 . Thus, the above research hypothesis is supported as presented in Table 7.

Table 7: The Significant Effect of Mental Health and Quality of work life

\begin{tabular}{cccccccc}
\hline Construct & Path & Construct & $\begin{array}{c}\text { Beta } \\
\text { Estimate }\end{array}$ & $\begin{array}{c}\text { Standard } \\
\text { Error }\end{array}$ & $\begin{array}{c}\text { Critical } \\
\text { Region }\end{array}$ & $\begin{array}{c}\text { P- } \\
\text { Value }\end{array}$ & Result \\
\hline JP & $<---$ & JS & .238 & .079 & 2.994 & .003 & Supported \\
\hline
\end{tabular}

H3: Employees' Job Satisfaction Has A Significant Influence On Their Quality Of Work Life.

As hypothesised, job satisfaction was found to be positively related to quality of work life $(\beta=0.847, p=0.001)$. According to the results, when job satisfaction went up by 1 , quality of work life also went up by 0.847 . Thus, the above research hypothesis is supported as presented in Table 8. 
Table 8: The Significant Effect Of Mental Health And Quality Of Work Life

\begin{tabular}{cccccccc}
\hline Construct & Path & Construct & $\begin{array}{c}\text { Beta } \\
\text { Estimate }\end{array}$ & $\begin{array}{c}\text { Standard } \\
\text { Error }\end{array}$ & $\begin{array}{c}\text { Critical } \\
\text { Region }\end{array}$ & $\begin{array}{c}\text { P- } \\
\text { Value }\end{array}$ & Result \\
\hline QWL & $<---$ & JS & .847 & .048 & 17.708 & $* * *$ & Supported \\
\hline
\end{tabular}

H4: Employees' Quality Of Work Life Has A Significant Influence On Their Job Performance. As hypothesised, quality of work life was found to be positively related to job performance $(\beta=0.622, p=0.001)$. According to the results, when quality of work life went up by 1 , job performance also went up by 0.622 . Thus, the above research hypothesis is supported as presented in Table 9.

Table 9: The Significant Effect Of Mental Health And Quality Of Work Life

\begin{tabular}{cccccccc}
\hline Construct & Path & Construct & Beta Estimate & Standard Error & Critical Region & P-Value & Result \\
& & & & & & & \\
\hline JP & $<---$ & QWL & .622 & .081 & 7.697 & $* * *$ & Supported \\
\hline
\end{tabular}

\section{H5: Quality Of Work Life Mediates The Relationship Between Job Satisfaction And Job Performance}

Hypothesis 5 examined the mediating effect of quality of work life, and it was hypothesised that quality of work life mediates the relationship between job satisfaction and job performance. In this study, the researcher assessed the direct effect, as well as the indirect effect of job satisfaction on job performance. Hence, if the direct effect of job satisfaction on job performance is significant, the researcher could determine if quality of work life mediated the relationship between job satisfaction and job performance. The role of a mediator is to provide an indirect effect of job satisfaction on job performance. Thus, the researcher tested the mediation effect using bootstrapping as discussed below.

\section{Mediation Effect Using Bootstrap Approach}

This study applied Preacher \& Hayes, (2008) method of bootstrapping the indirect effect to determine the presence of mediation effect. As discussed earlier, mediation occurred when the lower bound (LB) and upper bound (UB) values of indirect effect do not straddle a 0 in between. Thus, the result of the analysis shows that the lower bound was 0.379 and the upper bound was 0.619 (both upper and lower bound are in a positive region) as presented in Table 10.

Table 10: Bootstrapped for Indirect Effect

\begin{tabular}{cccc}
\hline Mediator & Standardised & \multicolumn{2}{c}{ 95\% Confidence Interval (CI) } \\
\cline { 3 - 4 } & Indirect & Lower Bound & Upper Bound \\
& Estimate & $($ LB $)$ & $($ UB $)$ \\
\hline $\mathrm{JS} \rightarrow \mathrm{QOL} \rightarrow \mathrm{JP}$ & 0.142 & 0.379 & 0.619 \\
\hline
\end{tabular}




\section{Type of the Mediation}

Next, to determine the type of the mediation (partial or full mediation), this research employed suggestions made by Mathieu \& Taylor (2006) and Baron \& Kenny (1986) as discussed earlier. The result of the analysis shows that the indirect effect $\beta=0.14(0.236 \times 0.62)$ were significant with a $p$-value of 0.003 . While the direct effect $\beta=0.84$ was also significant with a $p$-value of 0.000 as presented in figure 4 . The type of mediation in this study is a partial mediation since both the indirect effect and direct effect are significant. Thus, it is concluded that the influence of job satisfaction on job performance is partially mediated by quality of work life.

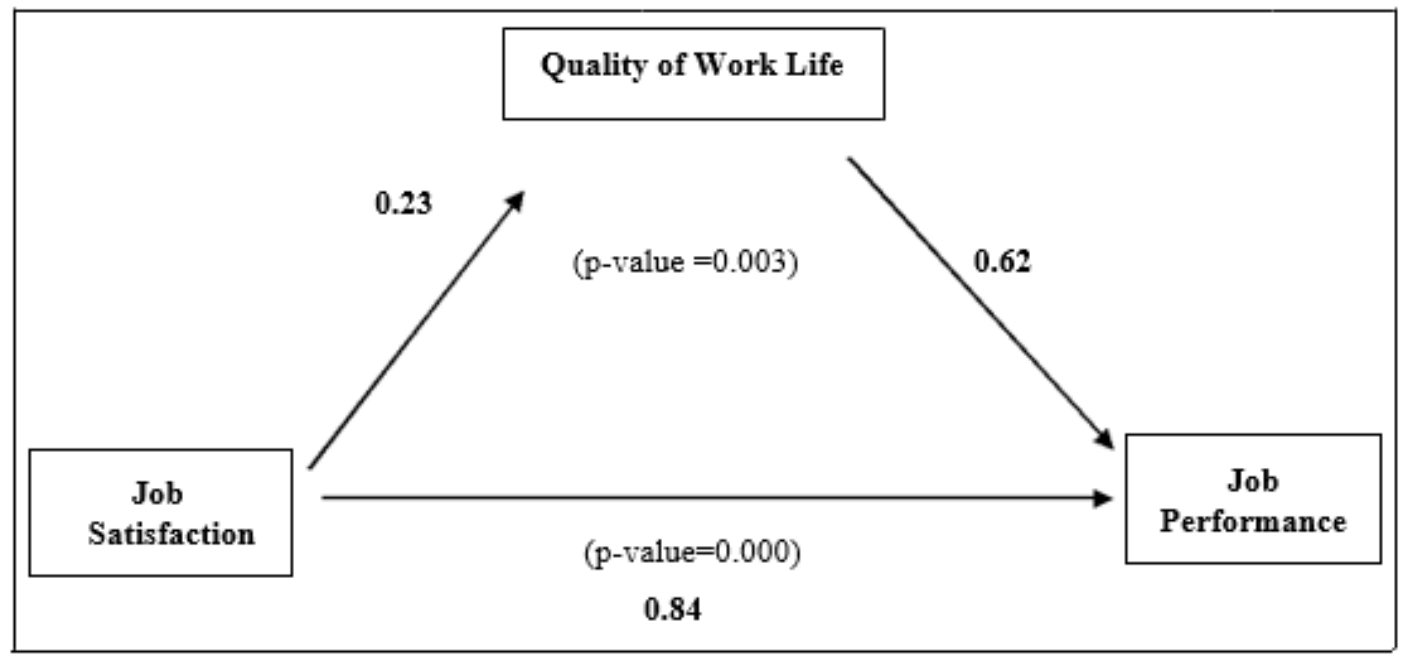

Figure 4: The Significant Mediation Model in Bootstrapping Result

Table 11: Summary of the Hypotheses

\begin{tabular}{lll}
\hline No & Hypotheses Statement & Results \\
\hline H1 & $\begin{array}{l}\text { Organisation structure has a significant influence employees' job } \\
\text { satisfaction in the Jordanian hotels sector }\end{array}$ & Supported \\
H2 & $\begin{array}{l}\text { Leadership style has a significant influence on employees' job } \\
\text { satisfaction in the Jordanian hotels sector }\end{array}$ & Supported \\
H3 & $\begin{array}{l}\text { Employees' job satisfaction has a significant influence on their } \\
\text { job performance in the Jordanian hotels sector }\end{array}$ & Supported \\
H4 & $\begin{array}{l}\text { Employees' job satisfaction has a significant influence on their } \\
\text { quality of work life }\end{array}$ & Supported \\
H5 & $\begin{array}{l}\text { Employees' quality of work life has a significant influence on } \\
\text { their job performance }\end{array}$ & Supported \\
H6 & $\begin{array}{l}\text { Quality of work life mediates the relationship between job } \\
\text { satisfaction and job performance }\end{array}$ & Supported \\
\hline
\end{tabular}

The table shows the summary of the hypotheses construed in this study. The entire hypothesis was outlined were all accepted because the model indicated significant at $\mathrm{p}<0.05$.

\section{Conclusion}

The present study discussed the findings from 430 usable questionnaires as drawing from analysis of the descriptive analysis, CFA, and SEM. The first part of the present study starts with the data coding, editing and screening prior to descriptive analysis. Next, this study validated the measurement models for all constructs involved in the study through the assessment of validity and reliability. 
The study employed CFA to validate the measurement models. The pooled CFA was conducted on the three constructs, namely job performance, quality of work life, job satisfaction, leadership style and organisational structure. Before SEM, the measurement models must meet the minimum required level for every assessment. For instance, factor loadings for every item must greater than 0.60 , and the overall goodness-of-fit indexes must exceed the criteria for model fit. The analysis of the path models in SEM found that for the four direct effects hypotheses, $\mathrm{H} 1, \mathrm{H} 1, \mathrm{H} 2$ and $\mathrm{H} 3, \mathrm{H} 4$, and $\mathrm{H} 5$ were supported. As for the mediation tests, H6 was also supported by partial mediation effects.

\section{References}

Afthanorhan, A., Awang, Z., \& Fazella, S. (2017). Developing the patients' loyalty model for medical tourism industry: the case of Malaysia. International Journal of Society Systems Science, 9(2), 139-164.

Afthanorhan, A., Awang, Z., Rashid, N., Foziah, H., \& Ghazali, P. (2019). Assessing the effects of service quality on customer satisfaction. Management Science Letters, 9(1), 13-24.

Afthanorhan, A., Awang, Z., Salleh, F., Ghazali, P., \& Rashid, N. (2018). The effect of product quality, medical price and staff skills on patient loyalty via cultural impact in medical tourism. Management Science Letters, 8(12), 1421-1424.

Akehurst, G., Comeche, J. M., \& Galindo, M.-A. (2009). Job satisfaction and commitment in the entrepreneurial SME. Small Business Economics, 32(3), 277-289.

Al-Rousan, M. R., \& Mohamed, B. (2010). Customer loyalty and the impacts of service quality: The case of five-star hotels in Jordan. International journal of human and social sciences, 5(13), 886-892.

Ao, S. I., \& Gelman, L. (2011). Electrical engineering and applied computing. Springer.

Awang, Z. (2014). A Handbook on Structural Equation for Academicians and Practitioners. MPWS Publication. Bangi. Malaysia.

Awang, Z. (2015). SEM made simple: a gentle approach to learning structural equation modeling. MPWS Rich Publication.

Awang, Z., Afthanorhan, W. M. A. W., \& Asri, M. A. M. (2015). Parametric and nonparametric approach in structural equation modeling (SEM): The application of bootstrapping. Modern Applied Science, 9(9), 58-67.

Aziz, M. I., Afthanorhan, A., \& Awang, Z. (2016). Talent development model for a career in Islamic banking institutions: A SEM approach. Cogent Business \& Management, 3(1), 1186259.

Bakker, A. B., Albrecht, S. L., \& Leiter, M. P. (2011). Key questions regarding work engagement. European journal of work and organisational psychology, 20(1), 4-28.

Bolden, R. (2004). The Future of Leadership: Synopsis of Initial Windsor Meeting Reports from September 2003-May 2004: Report for the Windsor Leadership Trust, Centre for Leadership Studies, Exeter.

Borman, W. C., \& Motowidlo, S. (1993). Expanding the criterion domain to include elements of contextual performance. Personnel Selection in Organisations; San Francisco: Jossey-Bass, 71.

Campbell, J., McCloy, R., Oppler, S., \& Sager, C. (1993). A theory of performance: In N. Schmitt \& WC Borman (Eds.), Personnel Selection in Organisations (pp. 35-70): San Francisco: Jossey-Bass.

Ekvall, G., \& Arvonen, J. (1991). Change-centered leadership: An extension of the twodimensional model. Scandinavian Journal of Management, 7(1), 17-26. 
George, D., \& Mallery, M. (2010). SPSS for Windows Step by Step: A Simple Guide and Reference, (10ed.) Boston: Pearson.

George, J. M. (1991). State or trait: Effects of positive mood on prosocial behaviors at work. Journal of applied Psychology, 76(2), 299.

Gravetter, F. J., \& Wallnau, L. B. (2016). Statistics for the behavioral sciences. Cengage Learning.

Hahn, S. E., Sparks, B., Wilkins, H., \& Jin, X. (2017). E-service quality management of a hotel website: a scale and implications for management. Journal of Hospitality Marketing \& Management, 26(7), 694-716.

Hair, Jr, J. F., Babin, B. J., \& Krey, N. (2017). Covariance-Based Structural Equation Modeling in the Journal of Advertising: Review and Recommendations. Journal of Advertising, 46(1), 163-177.

Hasan, M. A., Sarkis, J., \& Shankar, R. (2013). Interpretive structural modelling of agility enhancing management practices for agile manufacturing. International Journal of Agile Systems and Management, 6(4), 361-390.

Hassi, A. (2018). "You get what you appreciate" Effects of leadership on job satisfaction, affective commitment and organisational citizenship behaviour. International Journal of Organizational Analysis, 2(1), 65.

Jackson, J. H., \& Cyril, P. Morgan. (1982), Organisation Theory: A Macro Perspective for Management: Englewood Cliffs, NJ: Prentice-Hall.

Kaliski, B. S. (2009). Encyclopedia of Business and Finance-Two-volume set: MacMillan Reference Books.

Katunze, M., Kuteesa, A., Mijumbi, T., \& Mahebe, D. (2017). Uganda warehousing receipt system: improving market performance and productivity. African Development Review, 29(2), 135-146.

Kinnie, N., Hutchinson, S., Purcell, J., Rayton, B., \& Swart, J. (2005). Satisfaction with HR practices and commitment to the organisation: why one size does not fit all. Human Resource Management Journal, 15(4), 9-29.

Kumar, J. R., \& Rajendran, R. (2018). Impact of Education and Work Environment on quality of work life in it sector. Mim international journal of management research, 3(1), 43.

Locke, E. (1976). The nature and causes of job satisfaction. V MD Dunnette (Ur.), Handbook of industrial and organisational psychology (pp. 1297-1350): Chicago: Rand McNally.

Lok, P., \& Crawford, J. (2004). The effect of organisational culture and leadership style on job satisfaction and organisational commitment: A cross-national comparison. Journal of management development, 23(4), 321-338.

Maduenyi, S., Oke, A. O., Fadeyi, O., \& Ajagbe, A. M. (2015). Impact of organisational structure on organisational performance. African Development Review, 2(2), 135.

Massam, B. H. (2002). Quality of life: public planning and private living. Progress in Planning, $58(3), 141-227$.

Mathieu, J. E., and S. R. Taylor. 2006. Clarifying conditions and decision points for mediational type inferences in organisational behaviour. Journal of Organisational Behaviour 27: 1031-1056.

McCall, M. W., \& Lombardo, M. M. (1983). Off the track: Why and how successful executives get derailed: Center for Creative Leadership.

Mintzberg, H. (1979). An emerging strategy of" direct" research. Administrative science quarterly, 24(4), 582-589. 
Mohamad, M., Ab Ghani, N. I., Mamat, M., \& Mamat, I. (2014). Satisfaction as a mediator to the relationships between destination image and loyalty. World Applied Sciences Journal, 30(9), 1113-1123.

Mohamad, M., Mohammad, M., Mat Ali, N. A., \& Awang, Z. (2018). The impact of life satisfaction on substance abuse: delinquency as a mediator. International Journal of Adolescence and Youth, 23(1), 25-35.

MOTA. (2013-2017). Toursim Statistical Newsletter. 04/25/. Retrieved from Available from: https://www.mota.gov.jo/Contents/Statistics.aspx.

Nabwire, M. (2014). Factors Affecting Implementation of Strategy A Case of Barclays Bank of Kenya. United States International University-Africa.

Nanjundeswaraswamy, T., \& Swamy, D. (2014). Leadership styles. Advances in Management, $7(2), 57$.

Preacher, K. J., \& Hayes, A. F. (2008). Asymptotic and resampling strategies for assessing and comparing indirect effects in multiple mediator models. Behavior research methods, 40(3), 879-891.

Quinlan, E., Crowe, T., Deane, F. P., \& Whittington, M. (2019). Functions of peer mentoring, satisfaction and the "real" relationship in postgraduate psychology education. International Journal of Mentoring and Coaching in Education, 8(1), 52-68.

Robbins, S. P. (2009). Organisational Behavior, 13/E: Pearson Education India.

Rojas, M. (2014). The Measurement of Quality of Life: Conceptualization Comes First A FourQualities-of-Life Conceptual Framework and an Illustration to Latin America: Mexico.

Rosenberg, P., \& Choufany, H. (2009). Jordan A Vital Tourism Sector. HVS Global Hospitality Services-Dubai. International Journal of Mentoring and Coaching in Education, 9(4), 87.

Sajtos, L., Snell, L., Sok, P., \& Danaher, T. S. (2015). Achieving growth-quality of work life ambidexterity in small firms. Journal of Service Theory and Practice, 6(1), 24-29.

Sanda, A., \& Arthur, N. A. D. (2017). Relational impact of authentic and transactional leadership styles on employee creativity: The role of work-related flow and climate for innovation. African Journal of Economic and Management Studies, 8(3), 274-295.

Schein, E. H. (2006). Organisational culture and leadership (Vol. 356): John Wiley \& Sons.

Sekaran, U., \& Bougie, R. (2010). Research Method for Business, A Skill Building Approach.: John Wiley \& Sons Inc. Singapore.

Sekaran, U., \& Bougie, R. (2016). Research methods for business: A skill building approach. (7th ed). New York, United States: John Wiley \& Sons.

Stogdill, R. M. (1974). Handbook of leadership: A survey of theory and research. Free Press.

Thompson, J. D. (1967). Organisations in action: Social science bases of administrative theory: Transaction publishers.

Tran, Q., \& Tian, Y. (2013). Organisational structure: Influencing factors and impact on a firm. American Journal of Industrial and Business Management, 3(2), 229.

USAID. (2006). Jordan Vision 2020 - Phase II. Retrieved from Available from: https://www.usaid.gov/sites/default/files/USAID_EGovernment_Update_FY2006.pdf.

Valaei,N. (2017). Organizational structure, sense making activities and SMEs' competitiveness: An application of confirmatory tetrad analysis-partial least squares (CTA-PLS). VINE Journal of Information and Knowledge Management Systems, 47(1), 16-41.

Valaei, N., \& Jiroudi, S. (2016). Job satisfaction and job performance in the media industry: A synergistic application of partial least squares path modelling. Asia Pacific Journal of Marketing and Logistics, 28(5), 984-1014. 
Walton, R. E. (1986). A vision-led approach to management restructuring. Organisational Dynamics, 14(4), 5-16.

Werner, J. M. (2000). Implications of OCB and contextual performance for human resource management. Human Resource Management Review, 10(1), 3-24.

Williams, L. J., \& Anderson, S. E. (1991). Job satisfaction and organisational commitment as predictors of organisational citizenship and in-role behaviors. Journal of management, 17(3), 601-617.

Yousef, D. A. (2000). Organisational commitment: A mediator of the relationships of leadership behavior with job satisfaction and performance in a non-western country. Journal of Managerial Psychology, 15(1), 6-24.

Zu, Q., Hu, B., Gu, N., \& Seng, S. (2015). Human Cantered Computing: First International Conference, HCC 2014, Phnom Penh, Cambodia, November 27-29, 2014, Revised Selected Papers (Vol. 8944): Springer. 